\title{
Colombia vista por el Norte: Imágenes desde el cine de Hollywood*
}

\author{
Yobenj Aucardo Chicangana-Bayona** \\ Paula Andrea Barreiro Posada**
}

Recibido: 2 de mayo de 2013 - Aprobado: 7 de junio de 2013

\begin{abstract}
Resumen
El presente estudio analiza cómo Colombia es representada por Hollywood en términos de lo bárbaro y lo exótico. Las imágenes de Colombia que nos presenta el cine de Hollywood se deben en gran parte a la influencia eurocéntrica de relatos exóticos hechos por viajeros, al avance económico y tecnológico de Estados Unidos en comparación con un aparente retraso en el desarrollo colombiano y a la visión general de un país suramericano, que según Hollywood, debe ser exótico. A partir del análisis de tres películas, Romancing the Stone; Delta Force 2: The Colombian Connection y Colombiana, argumentamos que, aunque Colombia se estereotipa como el país en el cual convergen enmarañadas geografías, insoportables climas e incivilizados habitantes, la visión de Hollywood apunta más a mostrar un país latinoamericano genérico, que no representa puntualmente las características propias de Colombia, sino que utiliza a dicho país como símbolo para escenificar lo suramericano en términos de lo violento.
\end{abstract}

Palabras clave: cine, Hollywood, estereotipos, Colombia, representación.

* El presente artículo forma parte de la investigación "Construcción cinematográfica de lo colombiano en el cine extranjero: paisajes, personificaciones y contextos" dentro de la línea Narrativas Audiovisuales, del grupo Comunicación, Periodismo y Sociedad, de la Universidad de Antioquia, y del proyecto "Fortalecimiento de grupos de investigación que soportan programas de posgrado de la Universidad Nacional de Colombia (2012). Grupo Historia, Trabajo, Sociedad y Cultura". Código Hermes 16093. Universidad Nacional de Colombia, Medellín.

** Profesor titular del departamento de Historia. Facultad de Ciencias Humanas y Económicas. Universidad Nacional de Colombia, sede Medellín. Doctor y magíster en Historia por la Universidade Federal Fluminense, Niterói, Brasil. Historiador de la Pontificia Universidad Javeriana de Bogotá y Técnico Cinematográfico de la Universidad Estácio de Sá, Rio de Janeiro, Brasil.yobenj@gmail.com, yachican@unal.edu.co

*** Profesora asistente del Departamento de Comunicación Social. Facultad de Comunicaciones, Programa de Comunicación Audiovisual y Multimedial. Universidad de Antioquia. Doctoranda en Artes, Universidad de Antioquia, Medellín, Colombia. Magíster en Media Arts de la Universidad de Arizona, Estados Unidos. labarreirap@gmail.com. 


\title{
Colombia seen form the North: images from Hollywood Film
}

\begin{abstract}
This article analyzes the way how Colombia has been represented by Hollywood in terms of barbarian and exotic features. Images of Colombia shown by Hollywood movies should be mostly due to the Eurocentric influence of exotic stories of travelers, the economic and technological development of the United States when compared to an apparent delay of the Colombian development, and the general view they have about a South American country that, according to Hollywood, should be an exotic place. From the analysis of three movies: Romancing the Stone; Delta Force 2: The Colombian Connection; and Colombiana, it is alleged that, despite Colombia has been stereotyped as a country where tangled geographies, harsh climates, and uncivilized inhabitants converge, the view of Hollywood is more addressed to show a generic Latin American country that does not specifically represent the characteristics incidental to Colombia but it uses such a country as a symbol to represent what is South American in terms of violence.
\end{abstract}

Key words: film; Hollywood; stereotypes; Colombia; representation. 


\section{Introducción}

Las investigaciones realizadas desde ámbitos interdisciplinares como el cine, la comunicación, la historia, la sociología y la antropología, que abordan la representación cinematográfica que se hace de un país, pueden agruparse en dos líneas de investigación generales. Una, la más abordada, analiza cómo cada país se representa a sí mismo. La otra, menos explorada, busca analizar cómo otros países y culturas representan a un país a través de la puesta en escena de la alteridad. Por tratarse de un arte capaz de vincular elementos provenientes de otras artes como la pintura, el teatro y la literatura, el cine se ha convertido en una herramienta óptima para escenificar las naciones y para la transmisión de valores culturales. Indagar por la manera en que un país es visto a través del cine permite reflexionar sobre las diversas formas artísticas en las que la identidad puede ser construida.

El interés por la búsqueda de la identidad colombiana se percibe en la proliferación de exposiciones, obras de teatro y series de televisión, que divulgan la trayectoria de Colombia con el fin de avivar la memoria histórica. Este interés también está presente en una variedad de investigaciones en las que los académicos-investigadores colombianos han demostrado interés por la construcción de lo colombiano en el cine nacional. Sin embargo, los estudios que indagan por la puesta en escena de lo colombiano en el cine extranjero son realmente escasos y es aquí donde indagar por la mirada externa se vuelve igualmente pertinente, y es el interés de este artículo, puesto que la identidad de un país no solo se construye internamente; el ojo ajeno también forma parte importante en esta construcción'.

Desde una perspectiva histórica y cinematográfica, el presente artículo analiza las representaciones de lo bárbaro y lo exótico que el cine de Hollywood hace de Colombia. Este análisis se apoya en tres películas, seleccionadas por destacar estas características, asociándolas a la geografía, el clima, la naturaleza y los habitantes de Latinoamérica y otras partes de mundo, las películas son: Romancing the Stone; Delta Force 2: The Colombian Connection y Colombiana. Los estereotipos encontrados en estos filmes no son originarios del cine, deben ser buscados en los relatos de viaje al continente Americano de los siglos anteriores, testimonios del encuentro entre culturas diferentes, que van a construir lo "exótico" como opuesto y diferente a lo europeo.

1 La escenificación de lo colombiano hecha por el cine extranjero, no solo revela importantes asuntos de identidad e imaginario nacional, sino que además permite presuponer implicaciones políticas y económicas. Así lo demuestra la nueva Ley de Cine colombiana, que "Fomenta el territorio nacional como escenario para el rodaje de obras cinematográficas"(Ley de Cine Colombiano 1556 de 2012). El Ministerio de Cultura, PROIMÁGENES Colombia y el Ministerio de Comercio, Industria y Turismo son las entidades que promueven esta Ley, lo que refleja un interés por impulsar a Colombia como destino turístico, incentivar la inversión extranjera y mejorar la imagen nacional ante el mundo. Hasta ahora, los esfuerzos estatales y publicitarios para promover una imagen positiva, han dado escasos frutos en la cinematografía internacional, que parece encontrar, no solo en Colombia sino en Latinoamérica, un referente de aventura peligrosa. 


\section{Metodología}

La metodología del presente estudio siguió un proceso estratégico para la selección de región, período y fuentes cinematográficas. Tomamos como región a Estados Unidos, por ser el país extranjero que más películas presenta sobre Colombia. Para el período de tiempo, dividimos el estudio en tres décadas, comenzando en 1980; esto con el objetivo de comparar la escenificación de lo colombiano a medida que trascurre el tiempo, a partir de un período en el que Colombia comenzó a estar más presente en el cine extranjero, debido a asuntos de narcotráfico y violencia. Por último, escogimos tres filmes que tuvieran a Colombia como narrativa central; de este modo, pudimos obtener suficiente material para el análisis audiovisual y narrativo.

El cine norteamericano nos presenta estereotipos sobre Colombia, que pasan por visiones de una república bananera, tropical, exótica, corrupta, con riquezas en su interior, pero también como un lugar peligroso, atrasado y rural, una tierra violenta donde el Estado es débil y el narcotráfico, los paramilitares y las guerrillas imperan.

Aquí entendemos el estereotipo siguiendo a Ernst Gombrich², como un esquema de representación, no necesariamente como algo negativo o positivo. Más que embarcarnos en juicios de valor, nos interesa entender el estereotipo, como un esquema simplificado que facilita la repetición y la comprensión fácil de informaciones, al punto de ser fundamental para aprehender lo desconocido y la otredad (Burke, 2005). Por su carácter esquemático y simplificado, el estereotipo se distancia de lo real, es limitado y es allí donde se genera la polémica.

\section{Relatos de viajes y representaciones visuales}

El capitalismo y el desarrollo económico y tecnológico de los países industrializados, con Estados Unidos a la cabeza, han establecido una escala evolutiva, es decir, diferentes grados y distancias entre los pueblos del mundo. El desarrollo, la civilización y el progreso son las metas de esa historia teleológica; entonces el resto de los pueblos y países del mundo solo pueden ocupar los escalones inferiores en esta visión del progreso (Chicangana, 2008).

Las representaciones de la alteridad construidas por el cine de Hollywood son herederas de los relatos exóticos, de las representaciones visuales y de las cartografías de los viajeros sobre los pueblos y las partes del mundo de los siglos XVI-XIX, que representaban la diversidad cultural, inventariando cuerpos, vestidos y artefactos. Los principales pueblos y naciones fueron representados en su singularidad y sus similitudes. Hombres y mujeres de diversas edades eran retratados con ropas y adornos típicos. Pero es importante resaltar que esas ropas y adornos no eran concebidos apenas como artefactos; constituían una forma de expresar apariencia, complexión, comportamiento y disposición de espíritu (Raminelli, 1999).

2 Ernst H. Gombrich, "La verdad y el estereotipo" En: Arte e ilusión, 1960. 
Los pintores y dibujantes de estos siglos trabajaban en sus obras con categorías de civilizado, relativamente civilizado y completamente incivilizado (Mason, 1998). Esas categorías establecidas por los europeos respondían a la relación sostenida por ellos con los diversos pueblos del mundo, más que a las propias características lingüísticas, étnicas o culturales de estos. Así, los grupos más dóciles y amigables con el europeo serían más civilizados que aquellos que ofrecieron una resistencia más fuerte a la colonización, considerados no civilizados, salvajes y primitivos. Esta tipología, obviamente, parte del punto de vista del europeo, situado en el ápice de la civilización y, como consecuencia, los otros pueblos estarían en diferentes niveles de inferioridad, visión que fue fortalecida con la expansión del imperialismo durante el siglo XIX.

Los paisajes y los tipos humanos representados por los artistas y viajeros debían ser pensados como un ambiente ecológico, es decir, como un todo. La historia natural incluía el estudio de los seres humanos como parte de la naturaleza, la fauna y la flora, reconociendo especies, hábitat y poblaciones. Entonces, si fueran representados gentíos "incivilizados" o "primitivos", el ambiente tendría que ser adecuado. Las pinturas de tipos humanos deberían permitir leer el nivel de desarrollo de la sociedad a través de sus artefactos culturales y también, por el ambiente natural que los condicionaba.

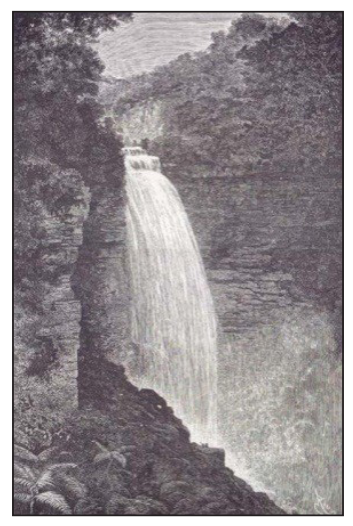

Riou. Salto del Tequendama. Grabado.

Biblioteca Luis Ángel Arango. Banco de la República. Bogotá. XIX.

Estos "grados de civilización" fueron presentados a partir de la indumentaria: mientras menos ropas, más primitivo. Entre más ropas y artefactos sofisticados, más desarrollados y más próximos de los europeos. Los criterios para medir los grados de civilización dependían de la distancia con relación al "ojo europeo" que los veía (Mason, 1998).

El contacto con el mundo natural en los siglos XVI-XVIII era tenue, es decir, copiar del natural, como actualmente lo entendemos, no era común en esta época. Autores como Smith (1988) y Mason (1998) discuten que la etnografía en las obras de los viajeros y los artistas era limitada, porque, a pesar de registrar detalles precisos de artefactos y adornos que les daban autenticidad a sus obras ante el espectador, demostraban no conocer su 
uso y funcionalidad en una determinada comunidad aborigen y, en otros casos, mezclaban artefactos de naciones y culturas diferentes. Esta aparente etnografía sería insípida, pues los artistas no tenían contacto e información con el indígena representado, ya que esto tampoco era de su interés.

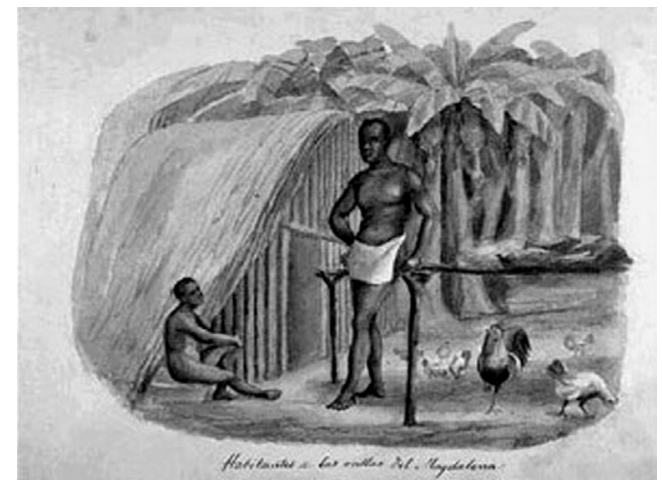

Ramón Torres Méndez. Habitantes a orillas del Magdalena. Acuarela. Biblioteca Luis Ángel Arango. Banco de la República. Bogotá. S. XIX.

Muchos de los pintores y los dibujantes que vinieron al Nuevo Mundo terminaron haciendo sus imágenes muchos años después o encomendaban a otros artistas la realización de las mismas. La validez de estas imágenes hechas años después del regreso a Europa, ya lleva a dudar de la veracidad y la autenticidad de lo que estaba siendo representado.

Entonces, para pintar, dibujar o grabar un nativo, el pintor no necesitaba conocer, haber tenido contacto o poseer informaciones confiables al respecto. Tendría sí, que dominar las convenciones del arte y la cultura que le permitirín la aceptación de sus obras por parte del público que las iba a consumir. Pero serán estas mismas convenciones las que funcionarán como filtro. A la hora de pensar en los estereotipos producidos por el cine aplica muy bien esta herencia cultural de los viajeros de los siglos anteriores.

\section{Representaciones sobre la alteridad}

Las representaciones visuales no deben considerarse como un registro fiel de la realidad; la aproximación del mundo visible es un proceso de aprender a mirar, a seleccionar y a encuadrar, en la medida que los esquemas sean más elaborados y sofisticados. Para describir el mundo visible en imágenes, fue necesario un sistema de schematas bien desarrollado. El artista encuentra en las convenciones del arte y de la tradición las herramientas para establecer coordenadas familiares, por medio de los esquemas. Sin ellos, no podría pintar, dibujar o grabar; sin códigos ganados con su experiencia, no podría representar lo que está delante de sus ojos, la otredad. Sucumbiría a las formas y a los colores.

El historiador francés Roger Chartier en su publicación El mundo como representación, entiende la representación como una imagen presente que vale por un objeto ausente, 
pues es su homólogo. Existe la posibilidad de que se tome al objeto presente como el remplazo real del ausente, considerando lo representado como la evidencia de una realidad que quizá no exista. Frente a este problema Chartier (1992) argumenta que "... Así encubierta, la representación se transforma en máquina de fabricar respeto y sumisión, en un instrumento que produce una coacción interiorizada, necesaria allí donde falla el posible recurso a la fuerza bruta..." (p. 59).

Este es el caso de la puesta en escena de lo colombiano hecha por la industria dominante de Hollywood, en el que se entiende que la representación proviene de un lugar de poder para generar sumisión ante lo que esta industria nos muestra como real.

Continuando por la línea de la representación como la superposición de un objeto en nombre de otro, el psicólogo rumano Serge Moscovici, en su texto La representación social: un concepto perdido, explica que la representación es la herramienta que usan las sociedades para acercar lo que está lejano. Según Moscovici (1979),

Un pueblo, una institución, un descubrimiento, etcétera, nos parecen lejanos, raros, porque no estamos ahí, porque se forman, evolucionan "como si no existiéramos", sin ninguna relación con nosotros. Representarlos lleva a repensarlos, a re-experimentar, a re-hacerlos a nuestro modo, en nuestro contexto 'como si estuviéramos ahí' (p. 43).

Este interés del ser humano por volver familiar lo que le resulta extraño es lo que lleva a la industria cinematográfica a representar países, culturas y naciones ajenas, reconstruyéndolas bajo la mirada de aquellos que están lejos para apropiarse de ellas.

En la representación cinematográfica de un país, son utilizados dispositivos estilísticos y narrativos para crear estereotipos vinculados a ciertos pueblos y culturas. Figurativamente, la expresión estereotipo se refiere a una caracterización repetida. La teórica Susan Hayward explica que el cine tomó el recurso del estereotipo del teatro melodramático para facilitar al espectador la comprensión temática. Por cuestiones de simplificación, el estereotipo ayuda a economizar tiempo en el cine, porque el espectador entiende más rápidamente el significado de lo que está siendo presentado, permitiendo que no haya necesidad de elaborar más en la caracterización (Hayward, 2010). Existen géneros cinematográficos que usan el estereotipo en mayor medida. Por lo general, estos géneros son los que necesitan de personajes (estereotipados) que sirvan de telón de fondo para el protagonista principal (Hayward, 2010). Así vemos cómo, por ejemplo, en las películas de acción, el héroe encarna valores positivos, y el antihéroe, los negativos.

La poderosa industria de Hollywood ha logrado permear diversas culturas, imponiendo su estilo de representar el mundo como una forma dominante y muchas veces consentida. Para Celestino Deleyto, la potencia icónica y representativa de Hollywood ha hecho que esta industria no solo hable de la historia, sino también, que forme parte de ella (Deleyto, 2003). Las sistemáticas representaciones culturales de Hollywood han construido un consenso ideológico que muchas veces consigue ser aceptado por los diversos grupos de espectadores. 
En el caso particular de Colombia, la representación que ha puesto en escena el cine de Hollywood ha girado en torno a temáticas de lo exótico y de lo violento, como si ambos temas fueran de la mano. El supuesto caos de este exótico país se debe a que sus enmarañadas geografías, insoportables climas e incivilizados habitantes hacen de este un lugar idóneo para que reinen el desorden y la violencia que lo convierten en un país primitivo, que necesita de la ayuda de países más desarrollados para poder resolver sus problemas.

Para evidenciar la puesta en escena de Colombia como una república de los trópicos, hemos seleccionado tres filmes producidos por Hollywood en tres décadas diferentes; esto nos permitirá analizar el tratamiento de lo colombiano en distintas épocas, lo que trae consigo implicaciones históricas, narrativas y sociales. Los filmes que estudiaremos son Romancing the Stone (Robert Zemeckis, 1984); Delta Force 2: The Colombian Connection (Aaron Norris, 1990) y Colombiana (Olivier Megaton, 2011). Las películas fueron seleccionadas por su enfoque central en el espacio y en los personajes colombianos. En el caso de Delta Force, el filme fue elegido por su interesante camuflaje del tema colombiano, escenificado en un país ficticio llamado San Carlos. Adicionalmente, Romancing the Stone y Colombiana, han sido seleccionadas por ser películas de grandes presupuestos que han alcanzado amplios niveles de distribución, llevando la imagen colombiana a través de múltiples fronteras.

El análisis de los tres filmes es centrado en el tratamiento estético y narrativo que se hace a personajes tanto colombianos como norteamericanos y las relaciones que estos tienen entre sí. De igual forma se estudia la puesta en escena de las locaciones colombianas, rurales y urbanas, en contraste con las de Estados Unidos. Esto nos permite tener un panorama de Colombia, sus habitantes y lugares, siempre en comparación con el lado norteamericano. Los estudios de caso de estos tres filmes nos revelarán cómo el país ha sido encasillado en estereotipos narrativos y estéticos que lo escenifican social y estéticamente como un lugar de complejos campos y ciudades, dando lugar a oscuros personajes e historias descarnadas.

\section{Colombia, una tierra de esmeraldas}

Romancing the Stone cuenta la historia de Joane Wilder, una escritora de novelas románticas del Oeste. Su vida transcurre en calma en New York hasta que recibe la llamada de su hermana Elaine, pidiéndole que vaya a rescatarla a Cartagena, Colombia, en donde termina secuestrada después de intentar recuperar el cadáver de su marido. El esposo de Elaine fue descuartizado a manos de un policía colombiano que busca obcecadamente un mapa que conduce a un tesoro en medio de la selva colombiana, una esmeralda de enormes proporciones. Joane debe llevar dicho mapa a Colombia para entregarlo a los secuestradores y salvar a su hermana.

En Colombia, Joane vive la peligrosa aventura que tantas veces enfrentaron sus personajes del Oeste. Allí, dos bandos están dispuestos a todo por recuperar el mapa y la gran esmeralda. El primer bando está compuesto por un pequeño grupo de traficantes 
norteamericanos; el otro bando, mucho más grande, está representado por las fuerzas militares y los policías corruptos del caribe colombiano. Al llegar a Colombia, Joane toma el autobús equivocado y en vez de dirigirse a Cartagena, se pierde en una selva espesa, en donde conoce al también estadounidense Jack Colton, su compañero en esta aventura.

Esta película de Hollywood fue dirigida por Robert Zemeckis y exhibida por primera vez en Estados Unidos en 1984. A pesar de tratarse de Colombia, ninguna de las locaciones pertenece realmente a este país, la película fue filmada en Veracruz (México), Nueva York, Utah y otras locaciones dentro de Estados Unidos, como el Parque Nacional Zion. Según la reconocida base de datos cinematográfica IMDb, por razones de seguridad el equipo de producción decidió filmar en Veracruz, luego de escuchar varios reportes de secuestros en Colombia.

Romancing the Stone es principalmente un filme de Estados Unidos, aunque México también participó como co-productor. En su reparto se encuentran tres estrellas de renombre en Hollywood, Michael Douglas, Kathleen Turner y Danny DeVito. Los costos de la producción alcanzaron los diez millones de dólares, una cifra muy alta considerando el año en que fue realizada. En tan solo su primer fin de semana de exhibición en Estados Unidos, la película recuperó la mitad de esta cifra, y en nivel mundial alcanzó la suma de US \$ 86.572.238 de taquilla. La película fue exhibida en más de diecinueve países, entre ellos Francia, Australia, Japón, Turquía y Argentina. Actualmente la importante cadena de televisión NBC planea hacer una versión del filme para televisión ${ }^{3}$. Esto no solo nos habla del éxito comercial de la película, sino también de la aceptación y del atractivo por la temática en aquella época y de los diversos escenarios mundiales a los que la imagen colombiana fue llevada.

La película embarca al espectador en un viaje de contrastes y aventuras por tres lugares radicalmente distintos. El filme inicia con una de las escenas de la última novela escrita por Joane. Luego de mostrar el árido y salvaje Oeste, el filme nos muestra la vida tranquila y solitaria de la escritora en la cosmopolita ciudad de New York. De la capital del mundo, el filme nos transporta a la selvática y caótica Colombia, donde Joane enfrentará sus miedos y encontrará el amor. New York, organizado y seguro, se nos muestra como el sitio ideal para vivir. El desierto del viejo Oeste donde dominan los criminales se nos compara metafóricamente con la vasta selva colombiana, en donde también impera le ley del más fuerte4. Una aproximación a la narrativa, el tratamiento de los personajes y a los paisajes de este filme nos mostrará el claro contraste que se hace entre un mundo moderno y un mundo de barbarie, en donde Colombia se escenifica como una exótica república de los trópicos, reducida al estereotipo de lo primitivo.

3 De acuerdo con The Hollywood Reporter, la serie se enfocará en misiones semanales en distintos lugares, lo que indica que la temática funciona sin tener que centrarse en Colombia.

4 Insinuando que las aventuras del Oeste que tanto disfrutaron los espectadores de este género, no se dan más en el desierto norteamericano, ahora la nueva aventura del cine de Hollywood se encuentra en tierras más distantes y agrestes. 


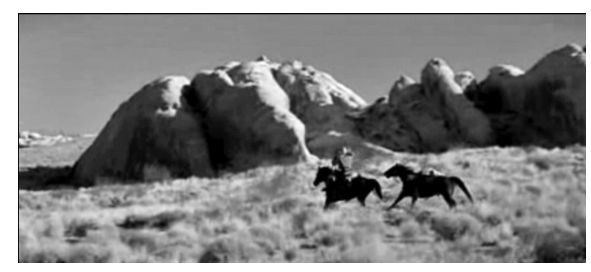

Imágenes de la novela romántica de Joane Wilder. El Oeste es presentado como frontera y como una tierra agreste escenario de grandes aventuras.

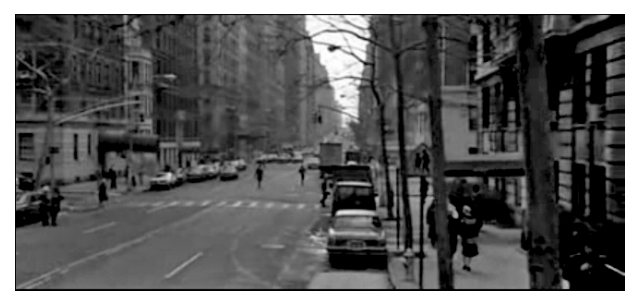

La fría, ordenada y moderna ciudad de New York al inicio del filme.

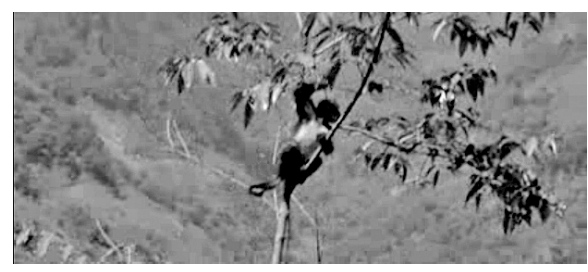

Primera imagen de la selva colombiana que ve Joane desde la ventana del autobús. Una tierra fértil y agreste apta para esconder tesoros.

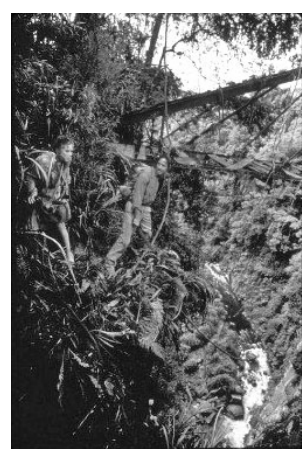

Joane y Jack sortean las difíciles condiciones de los caminos perdidos en la selva colombiana. Precipicios, puentes rotos y trochas componen el paisaje de la aventura. 


\section{Villanos y héroes}

En Romancing the Stone, los personajes principales son norteamericanos, a excepción de Zolo, el corrupto policía colombiano que asesinó al cuñado de Joane por robarle el mapa. Los personajes colombianos son extras transitorios que tienen roles de poca o nula importancia, casi siempre están al servicio de los norteamericanos o ayudando a Joane y Jack a lograr su cometido. Podría pensarse que el personaje principal colombiano es la misma Colombia, pues la relevancia que se le da al país a lo largo del filme hace que se convierta en el eje central de la narrativa y de las vidas de los otros personajes.

Dentro de los personajes principales están la escritora Joan Wilder, una mujer tímida y obsesionada por las historias del Oeste; Jack Colton, compañero de aventura de Joane que llegó a Colombia en un barco que cargaba café y se quedó traficando aves exóticas. Finalmente está Ralph, un norteamericano traficante de esmeraldas, encargado de darle el toque cómico a la historia con su rol de criminal ineficiente.

Las diferencias entre los colombianos y los estadounidenses son planteadas también por la narrativa y por la estética. Más allá de que los norteamericanos sean rubios y de ojos azules y que los colombianos tengan rasgos aindiados y cabellos oscuros, la actitud general de los colombianos los diferencia de los extranjeros. Los comportamientos de los colombianos en este filme son reducidos a dos tipos: el primero, ser sumisos, sobre todo en el rol de las mujeres y los sirvientes, ninguno de los dos tiene voz en el filme. El segundo, ser despiadados; los criminales colombianos son mucho más descarnados que los traficantes extranjeros. Quizá por eso el castigo final a los villanos colombianos es más duro que el propinado a los traficantes estadounidenses; por ejemplo, al final de la historia, Zolo pierde un brazo de un mordisco de cocodrilo y luego termina quemado vivo, entretanto que Ira, uno de los traficantes norteamericanos, logra escapar en un bote a Estados Unidos.

Muchos de los personajes colombianos que hablan español tienen un notable acento mexicano, entre ellos el propio Zolo. Esto es comprensible por el origen de la co-producción con México, pero también presenta una imagen de los hispanos homogeneizada, en donde sin importar la procedencia u origen, todos hablan con el mismo acento 5 .

\section{Civilización y barbarie}

Estados Unidos y Colombia se nos presentan como lugares de contrastes; el desierto, la capital del mundo y la selva, tienen situaciones opuestas que ofrecer. Lo agreste del desierto del oeste norteamericano es comparado metafóricamente con lo selvático del territorio colombiano; los dos surgen como lugares sin ley, donde se cometen crímenes que son cobrados por los mismos habitantes que toman la ley en sus propias manos.

5 Los 80 serán una década en que Latinoamérica será mexicanizada, en parte, porque se convierte en el principal referente de estos países y porque será el escenario principal para las producciones cinematográficas de Hollywood durante esta década. En películas como Superman III (1983) y Let's Get Harry (1986) para representar a Colombia se usan locaciones en México. Más tarde también sucedería lo mismo con películas como Clear and Present Danger (1994) y Collateral Damage (2002). 
El desierto se enmarca en planos generales que dejan ver la inmensidad de la tierra y el azul del cielo; esto se contrasta con los colores fríos del invierno en New York. En esta ciudad priman los planos generales de calles grises, rascacielos, árboles deshojados por el invierno y personas apuradas bajo la nieve vistiendo grandes abrigos. Una música tipo balada sofisticada acompaña estas imágenes. Más tarde, cuando Joane llega a Colombia, la música se torna alegre, exóticos tambores anuncian la llegada a una ciudad tropical. Esta música se va mezclando con sonidos de un piano misterioso que anticipa que este es el lugar en donde la acción peligrosa está por suceder.

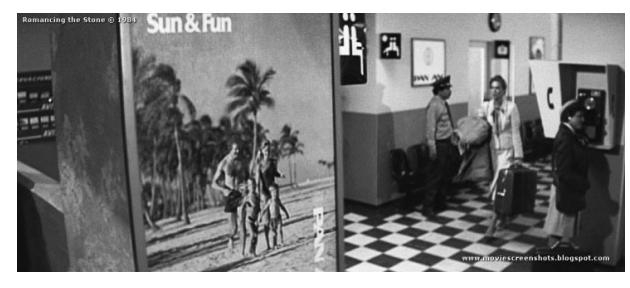

Aeropuerto de Cartagena, lugar que promete sol y diversión en familia

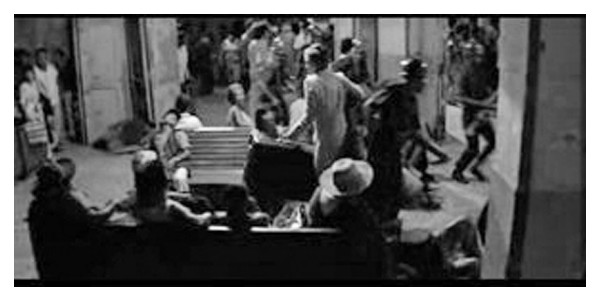

Paneo que muestra las afueras del aeropuerto en Cartagena, primer contacto de Joan con las personas y la cultura colombiana.

Al llegar al aeropuerto de Cartagena, un aviso promocional de turismo promete sol y diversión; inmediatamente después se escucha el chillido de un cerdo, al tiempo que la cámara hace un paneo para mostrarnos el caos al que ha arribado Joane. Tumultos de pasajeros sudorosos y ebrios, vendedores ambulantes, policías, ladrones que son perseguidos, calles sucias y mojadas, construcciones en mal estado, buses coloridos y casi desbaratados hacen parte de la primera impresión que se tiene de Colombia. En escenas diurnas, los planos generales muestran las amplias playas de Cartagena con personas en trajes ligeros, cielos abiertos y palmeras en donde el colorido del paisaje contrasta con el gris de New York. El Castillo de San Felipe ${ }^{6}$, locación en donde sucederán eventos clave de la narrativa fílmica, luce tosco y exótico, con paredes roídas y caimanes hambrientos.

6 En realidad se trata del Fuerte de San Juan de Ulúa, ubicado en Veracruz, México. 
Cuando Joan decide viajar a Colombia para rescatar a su hermana, la editora de sus libros, Gloria, le dice: "¿Colombia? ¿Tienes alguna idea de cómo es Colombia? Yo sí, tus libros se venderán muy bien en estos países machistas, allá tienen selvas, Joane, insectos del tamaño de los camiones de saneamiento y revolucionarios. ¿Te pusiste tus vacunas?" Joane hace caso omiso a todo esto, sin imaginar que su aventura no tendría lugar en las playas de Cartagena, sino en la exótica selva que su amiga le advertía.

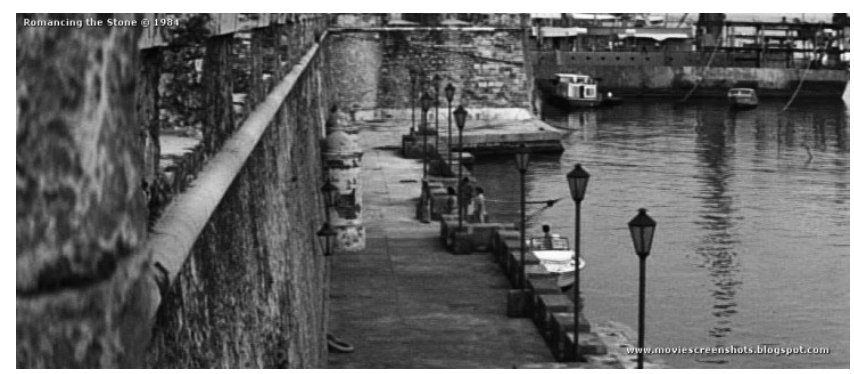

Supuesto Castillo de San Felipe, locación utilizada para añadir a la narrativa un ambiente exótico, tosco y antiguo.

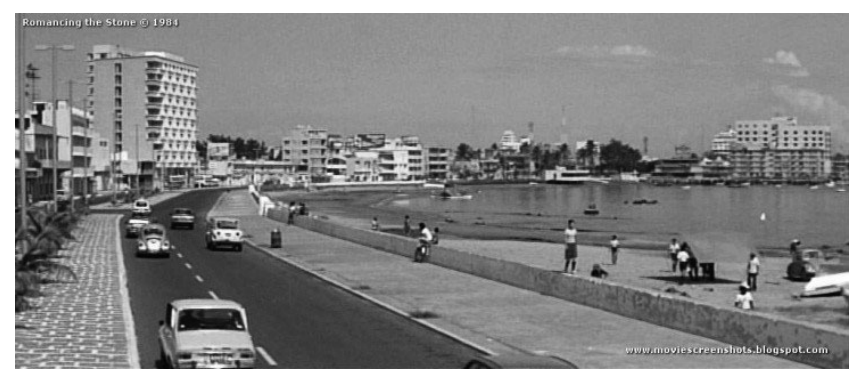

Panorámica atropical de Cartagena, en la que se aprecia la grana diferencia con el paisaje frío de New York.

Al igual que el desierto norteamericano, la selva y los pueblos colombianos parecen ser lugares perfectos para cometer toda clase de fechorías y crímenes. La aventura en busca de la esmeralda se da cerca de un caserío llamado Sabanalarga, en un bosque húmedo tropical de lluvia implacable, rodeado de montañas con monos colgando de los árboles, matas de plátano, imponentes cascadas y caminos de lodo. Este extenso territorio parece ser la tierra de nadie en la que rara vez se ven personas, incluso Joane y Jack encuentran un avión cargado de marihuana abandonado en medio de la selva. Aparentemente el avión se estrelló y no fue hallado, dando la sensación de que la selva esconde tesoros y misterios que permanecen ocultos por largo tiempo. 
Dentro de tantas aventuras, Joane y Jack llegan a un pueblo casi fantasma en busca de un transporte que los saque de ahí; sus únicos habitantes son narcotraficantes. Llamas, burros y casas roídas componen el paisaje. Uno de los habitantes se dirige a Joane en un inglés muy limitado, casi emulando el hablar tosco de los indios en las películas del Oeste. En otra ocasión camino a Cartagena, ambos arriban a un pueblo colombiano de nombre no especificado. En preparación para la fiesta Patronal que habrá esa noche, la plaza está completamente decorada con papeles coloridos, guirnaldas y piñatas al estilo mexicano. Las mujeres visten faldas campesinas para la gala y tímidamente sostienen pequeñas banderas ${ }^{7}$ colombianas en sus manos, quizá utilizadas como recurso simbólico para enfatizar que se trata de un poblado colombiano. En la fiesta, niños y adultos se entretienen por igual, bailando y comiendo en la calle, mostrando la alegría del pueblo colombiano.

\section{Redescubriendo a Colombia}

En Romancing the Stone se nos presenta una visión contemporánea de la conquista. La relación de los norteamericanos con Colombia en este filme fue netamente utilitarista, tal y como lo exhibe Ralph cuando le dice a su compañero Ira: "Hemos robado lo suficiente de estas baratijas antiguas que nos mantendrán viviendo cómodamente durante el resto de nuestras vidas. Despidámonos de este baño del Tercer Mundo." Esta frase sobre la explotación colombiana refleja incluso el tratamiento de segunda categoría que se les da a los pocos elaborados personajes colombianos, construidos para que funcionen como telón de fondo para las acciones de los norteamericanos y no se roben el show.

No solo se puede pensar a Colombia en términos de explotación de recursos y personas, sino también del terreno virgen y salvaje que sacia la curiosidad de los viajeros y les reconfirma que el lugar de donde ellos provienen es privilegiado. Colombia, como uno de los personajes principales de este filme, se pone en escena como una república de barbarie. A pesar de que Joan y Jack encuentran el amor y el dinero que les dio la esmeralda colombiana, la imagen del país, de sus habitantes y sus geografías, fue consistentemente escenificada en términos denigrantes, en los que ni siquiera lo exótico logró hacer alusión completa a aspectos menos negativos de la zona. Es así como Colombia alcanza el nivel de antagonista, de personaje casi villano que agobia y enreda a los turistas con su intrincada geografía para esconder en lo más profundo de sus entrañas los tesoros más codiciados. Esto pudo tener implicaciones en el imaginario internacional colombiano, considerando el gran éxito mundial del filme y la cantidad de países por los que esta imagen colombiana viajó.

\section{Delta Force II, the Colombian Connection}

Delta Force II, the Colombian Connection, es la historia de una organización de narcotraficantes colombianos que distribuyen cocaína a Estados Unidos. Los hechos tienen lugar a comienzos de los años 90 cuando la preocupación por el crecimiento del narcotráfico

$7 \quad$ Recurso estético muy utilizado en el cine de Hollywood para decorar fiestas nacionales e indicar el país en el cual ocurre la celebración. 
colombiano embargaba a los norteamericanos. Agentes de la DEA encargan al comando antiterrorismo Delta Force, liderado por el coronel Scout McCoy, para liberar a Estados Unidos del flagelo de las drogas provenientes de Colombia, orquestadas por el máximo narcotraficante Ramón Cota. Scout, y su compañero de trabajo Bobby, logran llevar a Ramón a la corte, pero este sale libre pagando una millonaria fianza. La nueva cacería del narcotraficante comienza cuando éste asesina a Bobby. El equipo entrenado del Delta Force viaja a lo que sería Colombia para poder atrapar al capo.

A pesar de que el propio título del filme lleve el nombre de Colombia, el país no se menciona como tal en la historia. Para referirse a Colombia la película usa el nombre de un país ficticio llamado San Carlos $^{8}$. La democracia de Estados Unidos se muestra sólida y potente, con sus incorruptibles e invencibles fuerzas militares y sus eficaces servicios de inteligencia; por el contrario, la democracia y la seguridad de San Carlos están en colapso. Debido a esa situación el presidente de San Carlos es manipulado por militares corruptos; así el ficticio país necesita ser salvado por otra nación más ordenada y poderosa, ya que por sí sola no puede, debido a sus múltiples problemas. Estas y otras polémicas razones pueden esconder el verdadero motivo de no mencionar específicamente a Colombia dentro de la narrativa, aunque sí se alude a dicho país utilizando sus símbolos patrios.

El Gobierno norteamericano, cansado de la droga que llega desde Suramérica, amenaza al presidente de San Carlos, el señor Alcázar, con no apoyarlo económicamente, si no se autoriza al ejército americano a ingresar al país y destruir todos los laboratorios y plantaciones de cocaína que se puedan encontrar. Alcázar termina cediendo a las presiones y permite que los Estados Unidos ingresen a su territorio; entonces, los militares del Delta Force entran disparando a aldeas, caseríos y poblaciones sin ninguna discriminación. De este modo, el filme muestra dos temas polémicos, el primero, Colombia y su imposibilidad de luchar contra el narcotráfico, y el segundo, el derecho al uso de la fuerza por parte de Estados Unidos sobre países donde consideran que está ausente una autoridad legítima y donde dominan el narcotráfico y otros tipos de criminales.

Delta Force II fue dirigida por Aaron Norris y se estrenó en Estados Unidos en 1990. La película hace parte de una serie de filmes y videojuegos bajo el nombre Delta Force, que exploraban distintos tipos de terrorismo en países que, de cierta forma, amenazaban la tranquilidad norteamericana9. Delta Force II, the Colombian Connection, fue rodada en Filipinas y Estados Unidos. Su presupuesto fue bajo y en Estados Unidos logró hacer un total de US \$6.698.361 en taquilla. Fue distribuida en doce países, entre ellos Hungría, Finlandia, Francia y Filipinas, y contó entre su reparto con la estrella del cine de acción, Chuck Norris. Los personajes, la narrativa, y los paisajes de este filme, al igual que en la película anterior, ilustran la interesante comparación cinematográfica que se hace entre un país seguro y civilizado y otro, caótico y exótico.

8 Quizá esto se deba a razones de producción, pues el filme inicialmente se llamaría Delta Force II: Operation Stranglehold, aunque quizá haya otras razones de peso para obviar y no especificar el nombre de Colombia.

9 El primer filme de esta serie narró cómo unos terroristas libaneses secuestran un avión y el Delta Force logró rescatar a la tripulación y reestablecer el orden. 


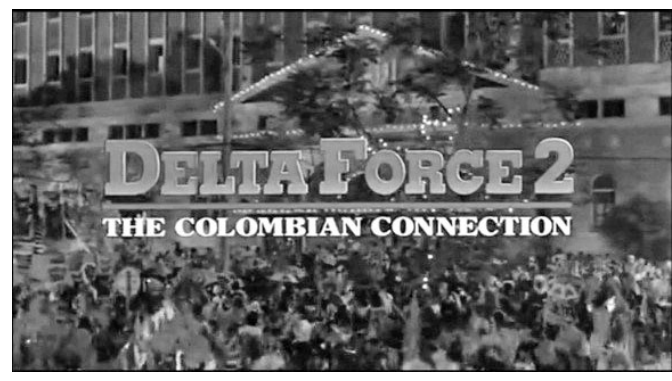

Colombia se menciona solo directamente en el título del filme.

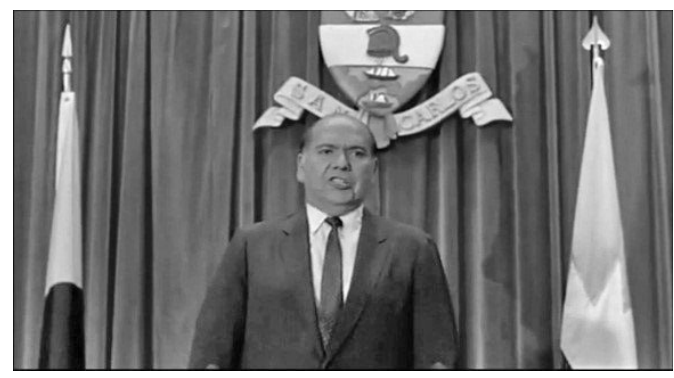

Algunos elementos de los símbolos patrios colombianos permanecen en el escudo del ficticio país de San Carlos, como los cuernos de la abundancia, el gorro frigio y el istmo de Panamá. También se observa la bandera colombiana a la izquierda del Presidente Alcázar.

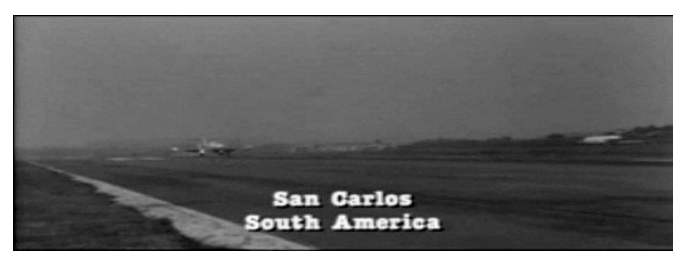

San Carlos, un país ficticio para referirse a Colombia.

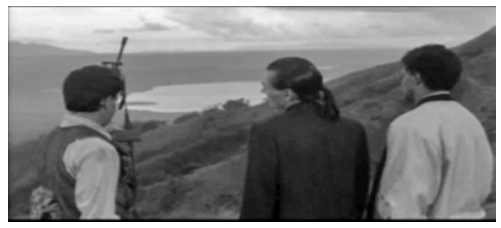

Terroristas colombianos contemplan una plantación de coca.

El capo de las drogas Ramón Cota en el centro. 


\section{Héroes americanos y villanos colombianos}

Del lado estadounidense podemos apreciar a las invencibles fuerzas militares, y del lado de San Carlos la variedad de personajes es más compleja. Desde la perspectiva norteamericana, todos los personajes involucrados en la narrativa disfrutan de la seguridad y el bienestar que les ofrece su país. Militares aguerridos y familias unidas gozan de las ventajas de vivir en dicha potencia mundial, que les ofrece prosperidad y tranquilidad. Los dos personajes principales del lado norteamericano son el coronel Scott McCoy, un defensor de los más débiles, como las mujeres y los niños. Scott encarna los valores contemporáneos norteamericanos al ser vigoroso, inteligente y honesto; y el general Taylor, quien ha dedicado toda su vida a defender la tranquilidad de su país, encarna el valor de los veteranos de guerra y simboliza el pasado guerrero y honorable de su país.

Campesinos e indígenas explotados, militares corruptos y narcoterroristas, componen el variado panorama de los personajes del lado de San Carlos. El personaje central del lado colombiano es Ramón Cota, el traficante de cocaína más rico del mundo, cabeza de la red de narcotraficantes colombianos que intoxican a los Estados Unidos con su droga. Cota encarna al antagonista del coronel Scott, representa sus antivalores, es despiadado con mujeres y niños, y asesinó personas injustamente en más de diecisiete países. Ayudando a que Cota controle el negocio de la droga, se encuentran el presidente de San Carlos, Alcázar, un líder ineficiente amenazado por el General Almeda, un militar corrupto beneficiado con el dinero del narcotráfico. Alrededor de estos personajes macabros están los campesinos e indígenas que trabajan silenciosamente recolectando la coca, al tiempo, que aguantan las injusticias de su patrón Ramón, que los amenaza constantemente con asesinarlos si no hacen lo que él les manda. San Carlos es mostrado como un país de contrastes, lleno de gente humilde y trabajadora de la que sus patrones y gobernantes abusan.

La confusa mezcla cultural y racial del filme hace de este un caso interesante para estudiar la representación de lo colombiano. Quizá por el hecho de haber rodado buena parte de las escenas rurales en Filipinas, gran parte de los personajes que interpretan campesinos o guardaespaldas colombianos son extras filipinos con características físicas bastante marcadas. Este aspecto genera confusión, porque no se tiene certeza de tratarse de Colombia, de San Carlos o incluso de un país oriental ${ }^{10}$.

En el filme, el carácter de lo colombiano se enmarca en paisajes rurales y personajes de piel más oscura que la de los norteamericanos, a quienes se les viste con poncho y sombrero para darles un toque suramericano. Esta escenificación es suficiente para diferenciar a Colombia de los Estados Unidos, pues lo importante es que el espectador diferencie entre lo que es civilizado y lo primitivo, entendiendo que en este caso, todo lo diferente a Estados Unidos debe ser asumido como colombiano.

10 Dentro del reparto también se encuentran dos actores bajo el nombre de "mujer y hombre vietnamitas". 


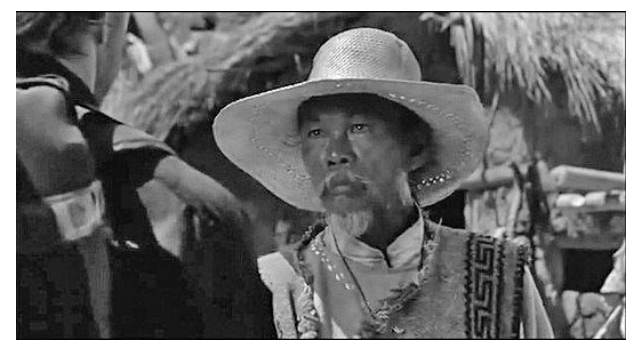

Este personaje, conocido como El Jefe, interpretado por el actor filipino Jerry Lapuz, presenta evidentes rasgos físicos filipinos u orientales que distan bastante del fenotipo hispano o colombiano. Sin embargo, su vestuario y color de piel bastan para personificar su origen hispano.

\section{Suburbios familiares y plantaciones de cocaína}

La vida en los Estados Unidos es simple y tranquila, entre tanto, en San Carlos el intrincado paisaje refleja la vida dura de sus habitantes. Los miembros del Delta Force disfrutan con sus familias en los barrios del suburbio, con casas amplias y confortables, similares entre sí. El clima no fue utilizado para marcar una diferencia entre Estados Unidos y San Carlos. En cambio, sí lo fue la ausencia de ciudades o al menos de pequeños pueblos o caseríos en este último país mostrado como un sitio completamente rural y tropical. Selva espesa, caseríos con algunas chozas donde habitan los campesinos e indígenas, puentes colgantes en mal estado y grandes lagunas, conforman el paisaje exótico de este supuesto país suramericano.

En Delta Force es usado el recurso de lo exótico para brindar un camuflaje a situaciones y personajes. Desde el inicio del filme lo exótico se hace presente al comenzar la historia con un carnaval en Río de Janeiro, donde los extravagantes disfraces son perfectos para ocultar a los terroristas. Río de Janeiro es mostrado como la puerta exótica de Suramérica, por la que se debe cruzar para entrar en otros países. Luego, en San Carlos, la alegría y el carnaval se cambian por un ambiente lúgubre y misterioso entre plantaciones de cocaína. Lo exótico de San Carlos son sus paisajes exuberantes y la extravagancia de sus villanos. Por sus propiedades de camuflaje, la selva se convierte en el terreno perfecto para que los grandes narcotraficantes lleven una vida tranquila y llena de lujos. Es el caso de Ramón y del general Almeda, que viven en elegantes mansiones en medio de las solitarias montañas.

\section{Entre la espada y la pared}

Un complejo mensaje político se esconde tras la aparente narrativa simple de esta historia de acción. La película se ubica en una época de conflicto entre Colombia (o San Carlos) y Estados Unidos por problemas de narcotráfico, que a comienzos de los años 90 alcanzan su clímax. Dicho en el filme por el mismo presidente Alcázar: "El general Taylor le ha dado una bofetada a cada ciudadano honorable de San Carlos, es cierto que tenemos un problema de narcóticos en nuestro país, y estamos luchando en contra de este, pero si 
América nos acusa de ser traficantes de droga, entonces nosotros acusamos a Estados Unidos de ser una nación de drogadictos". Lo cierto es que San Carlos es mostrado como un país entre la espada y la pared, en medio de las amenazas del Gobierno estadounidense y las extorsiones de los capos de las drogas, que justifican sus actos bajo la premisa de que San Carlos es un país soberano, no un títere de los Estados Unidos.

El complejo mensaje político de Delta Force II fue suavizado estratégicamente al lograr distraer la atención directa del espectador hacia Colombia. Al no darle crédito específico a un país, la historia puede confundir al espectador frente al lugar donde los hechos violentos están ocurriendo ${ }^{11}$. Sin embargo, más allá de una intención de confundir al espectador con el lugar de los hechos, lo que resulta aún más interesante es la capacidad que tiene el filme de transitar entre etnias y culturas diferentes para representar lo colombiano, así, da lo mismo un actor filipino o uno mexicano. Quizá esta estrategia no solo haya sido utilizada para reducir los costos de la producción, sino que también funciona como recurso estético para construir cinematográficamente la alteridad colombiana como un país latino genérico.

Esta imprecisión en la representación étnica y la alteración entre culturas lejanas a la norteamericana también puede deberse a que el tipo de espectador que disfruta de esta película de acción va en busca de los efectos, las explosiones y la acción como tal, y puede no estar tan interesado en saber en qué lugar específico ocurren los hechos, mientras estos funcionen para la trama. Las galerías de villanos y lugares remotos apoyan la narrativa de manera que generan en el espectador esa sensación de remoto y de exótico. Los adversarios que enfrentan a los héroes americanos deben representar nuevos desafíos que deben ser superados; por eso los diversos antagonistas que enfrenta el Delta Force se encuentran en los lugares más insospechados del mundo, en regiones exóticas y tipos humanos de los más variados, lugares donde tienen que ir con la misión de establecer el orden y el imperio Americano.

\section{“Colombiana, una escandalosa mezcla de acción, sexo y violencia"}

Colombiana cuenta la historia de Cataleya, una mujer que durante su infancia fue testigo del asesinato de sus padres a manos de poderosos mafiosos, en un peligroso barrio de Bogotá, Colombia. Luego de escapar de los asesinos de sus padres, Cataleya es llevada a Estados Unidos por el Gobierno colombiano como parte del programa de protección, para que comience una nueva vida. Allí, será criada y entrenada por un tío que emigró años antes a Estados Unidos; como resultado, Cataleya opta por convertirse en una sicaria en vez de buscar una vida más tranquila y pacífica. Durante el tiempo que trabaja para su tío, Cataleya se convierte en una temida asesina en serie con el objetivo de vengar la muerte de sus padres.

11 Se logra camuflar el país de origen, aunque el título del filme menciona directamente a Colombia, al igual que los símbolos patrios usados en algunas escenas, como las constantes banderas colombianas que aparecen en uniformes y construcciones, un ejemplo puede ser el escudo nacional que aparece en el Palacio Presidencial de San Carlos. 
Colombiana es una película ambiciosa y polémica, escrita y producida por Luc Besson, director de los filmes El Perfecto Asesino y El Quinto Elemento, y de la serie de televisión La Femme Nikita, todos proyectos caracterizados por una poderosa presencia femenina, al igual que ocurre en Colombiana. La película se realizó en co-producción con Francia, y se estrenó en 2011 a escala mundial. La producción costó cuarenta millones de dólares y hasta el momento ha logrado ganar más de sesenta millones de dólares en taquilla en el mundo. Colombiana fue rodada entre la Ciudad de México y varias locaciones en Estados Unidos, nada se filmó en Colombia.

La película se ha distribuido en más de cuarenta países, incluyendo Colombia, en donde se exhibió bajo el título de Venganza Despiadada, probablemente para evitar críticas o polémicas por el título original, como sucedió en New York con indignados espectadores y organizaciones de inmigrantes colombianos que protestaron por la forma en que el filme estereotipaba la imagen del país y sus mujeres. Tal vez eso explique el corto período de exhibición de la película en los cines colombianos.

Uno de los afiches del filme tiene una crítica de Los Angeles Times que promueve la historia como una "Escandalosa mezcla de acción, sexo y violencia." El análisis sobre la puesta en escena de los personajes y las locaciones del filme nos permite corroborar el eslogan del afiche.

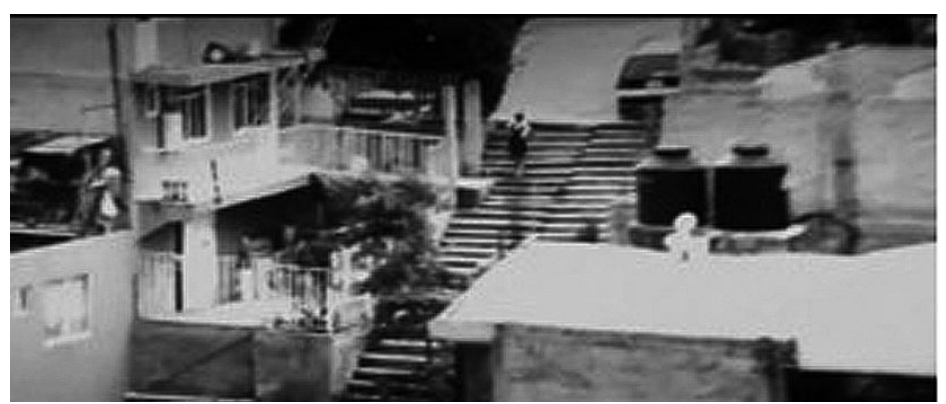

Toma aérea de un peligroso barrio ubicado en la periferia de Bogotá. Humildes casas de colores brillantes y calles empinadas con escaleras, adornan el exótico paisaje.

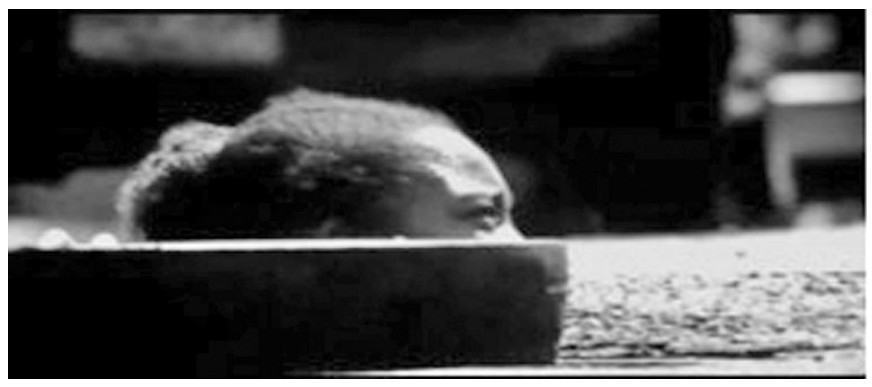

Cataleya encuentra refugio en una alcantarilla de Bogotá para huir de la violencia. 


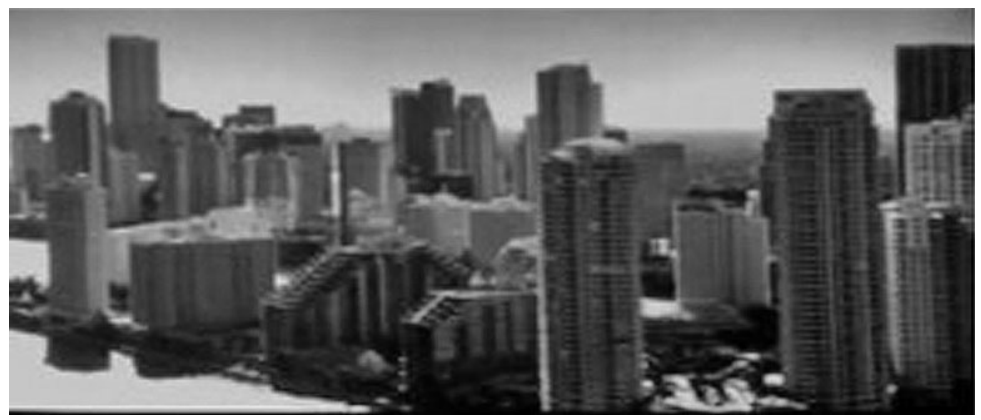

Toma aérea de ordenadas y modernas ciudades americanas que contrastan con las imágenes presentadas por la película sobre Colombia

\section{Una orquídea en la selva de concreto}

Colombiana nos transporta a los años 80 en Colombia y luego continúa en el tiempo presente en los Estados Unidos. Las diferencias económicas entre ambos países son notables y aunque pareciera que también lo son las diferencias sociales, la mirada al bajo mundo norteamericano, que provee el filme, deja ver que en Colombia los crímenes se cometen a puertas abiertas y en los Estados Unidos existen redes y un bajo mundo de delincuentes y asesinos que operan desde las sombras. Los personajes estadounidenses que se destacan son los agentes especiales del FBI, Ross y Richard. El primero es un hombre entregado a su servicio, el segundo aparenta importarse con la seguridad de su país, cuando en realidad, maneja negocios sucios con mafiosos colombianos. También sobresale Danny, el hombre que estimula la sensualidad de Cataleya y por momentos le hace olvidar lo dura que ha sido su vida.

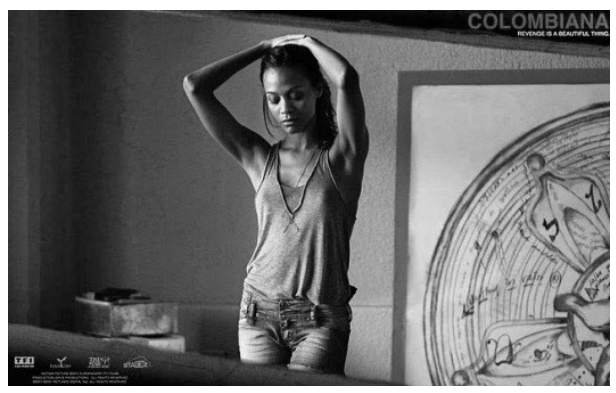

Cataleya baila sensualmente frente a la pintura de una exótica orquídea colombiana, la flor nacional la Orquídea Cattleya Trianae, de donde viene el nombre de la protagonista.

La mayoría de los personajes en esta película son colombianos y todos son de oscuro accionar. La protagonista de esta historia es la colombiana Cataleya, llamada igual que la orquídea Cattleya Trianae, la flor nacional de Colombia. En una escena, se la ve bailando sensualmente en su apartamento frente a una pintura con una inmensa orquídea rosada; 
esta escena establece una metáfora entre la exótica flor y la sensual mujer latina. Desde niña Catleya era aguerrida y temeraria, soñaba que al crecer sería como Xena, la hermosa princesa guerrera. Ya de adulta, además de poseer estas cualidades, era exóticamente sensual. Catleya encarna el estereotipo de la atractiva sicaria colombiana, bella y peligrosa'2 Rodeando a este personaje se encuentran los mafiosos y asesinos colombianos, como don Luis, un importante capo que mandó asesinar al padre de Cataleya; Marco, el asesino que trabaja para don Luis; y Emilio Restrepo, el tío sicario de Cataleya, quien le enseñó a ser como él. Los personajes colombianos son siniestros, sin remordimiento, ajustados a los estereotipos de gánster criollo con ropas tropicales, bigotes y crucifijos en el cuello.

\section{Dos mundos opuestos}

La película Colombiana enfatiza con gran fuerza visual el impresionante paisaje de las ciudades. A diferencia de las dos películas analizadas anteriormente, esta historia no muestra el lado rural colombiano o de los Estados Unidos; por el contrario, acentúa las características de las ciudades, como queriendo declarar por medio de estas, las grandes diferencias entre el mundo urbano moderno y el de la barbarie.

La Bogotá que se muestra es la de los años 80 , cuando el conflicto del narcotráfico cobró vigor, y el capo más famoso del mundo, Pablo Escobar, puso el nombre de Colombia en el mapa mundial. Los créditos iniciales del filme abren con tomas aéreas que dejan ver el hacinamiento que se vive en los supuestos peligrosos barrios periféricos de Bogotá. Este montaje inicial muestra imágenes a color de montañas saturadas con casas pequeñas y calles empinadas, alternadas con imágenes en tonos azules y negros, al estilo de imágenes de archivo documental, que muestran policías, cárceles y delincuentes, planos detalle de armas y granadas, helicópteros, perros antinarcóticos, Pablo Escobar apareciendo en la televisión, crucifijos y cadenas. La crudeza de las imágenes se va acrecentando hasta que la cámara hace una toma aérea final de la cima de la montaña, para ubicar allí el título del filme, Colombiana, dando la connotación de que las imágenes que pasaron son un resumen que define al país. Inmediatamente después de estas crudas imágenes, la secuencia es cortada y la pantalla se vuelve negra para dar paso a la extravagante mansión de don Luis, con cascada interior y guardaespaldas en cada esquina.

La sensación permanente transmitida por el filme es que Bogotá está a punto de estallar. Esta impresión no solo es lograda por el dolor que se ve en sus calles, sino también por el insoportable calor típico del trópico, lo que resulta irónico, tratándose en realidad de una ciudad fría y lluviosa. La persecución que hacen los mafiosos a Cataleya nos permite ver de cerca las calles del peligroso barrio y entrar en algunas de sus casas. Fachadas coloridas, casas con estructuras de lata o madera y mercados llenos de frutas y legumbres de colores vivos, hacen que el paisaje sea al mismo tiempo pintoresco y bárbaro.

12 Según Stacey Alba D. Skar (2007), este estereotipo es conocido en el mundo por medio de películas como Rosario Tijeras, una co-producción entre México, España, Brasil y Colombia y por María Llena Eres de Gracia, un filme co-producido entre Colombia y Estados Unidos, que trata el narcotráfico desde la perspectiva femenina. 
Al bajar del barrio en la montaña al centro de la ciudad, se nos muestra brevemente a una Bogotá más ordenada y limpia, diferenciando claramente entre el caos de la periferia y el orden del centro citadino. Estas imágenes de la ciudad son contrastadas con imponentes rascacielos norteamericanos.

Igual al comienzo del filme, pero de forma más contundente, las escenas muestran inicialmente a los Estados Unidos con un barrido aéreo de los lujosos e imponentes rascacielos de Miami y Chicago. Orden y modernidad son reflejadas por las calles bien planeadas. Estas tomas aéreas de flamantes edificios son utilizados como constantes transiciones entre escenas durante todo el filme, reafirmando el nuevo lugar en el que se encuentra Cataleya. Luego de viajar por algunas ciudades, Cataleya finalmente logra llegar a un peligroso gueto en Chicago, donde vive su tío colombiano, un lugar que le recuerda su lugar de origen, tal y como fue aconsejado por su padre antes de morir, "Nunca olvides de donde viniste."

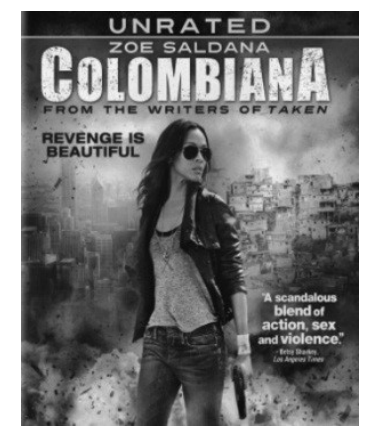

Afiche oficial de la película en el que se aprecia a la colombiana dividiendo dos mundos. A su derecha vemos el pasado doloroso en una ciudad caótica y a su izquierda vemos el futuro promisorio en una ciudad moderna y ordenada.

\section{Trópicos de violencia y mafia}

Gánsteres criollos y sicarias sensuales son los personajes que representan a los colombianos en este filme, en el que las posibilidades para referirse a Colombia se reducen a temas de violencia y mafia. En esta historia no se mencionan carteles de drogas; el origen del dinero de los capos queda incógnito, haciendo que las imágenes de crimen y violencia que se muestran en los créditos iniciales dejen la inquietud de la razón de tanto horror en este país. Unos personajes de este tipo solo pueden desenvolverse en un país de impunidades, en donde hasta el mismo paisaje citadino es duro. El mensaje final es que en Colombia, Cataleya solo encontró dolor, y en Estados Unidos, el amor y la venganza buscadas. Sin embargo, a pesar de que el país moderno y civilizado le ofreció mejores caminos, la colombiana viajó allí para reproducir el mundo del que venía, trayendo dentro de sí el desorden y caos de los trópicos para las ciudades americanas.

El polémico título de este filme genera dudas de tipo social y comercial. El solo hecho de que la película se llame Colombiana, connota una generalización que apela a todas las 
mujeres de este país, reduciendo su imagen al estereotipo de bellas, violentas o sicarias. Un slogan, usado en casi todos los afiches del filme, vende la historia bajo la promesa: "La venganza es bella", refiriéndose a la belleza casi cruel de la mujer colombiana. Vale la pena preguntarse el porqué del título del filme; quizá se deba a algún estereotipo de la mujer colombiana que exista en Estados Unidos y que favorece comercialmente la película, atrayendo a los espectadores desde el mismo momento en que estos leen el título.

Una posible evidencia de la existencia de este estereotipo en Estados Unidos es que la película llegó a otros países bajo otros títulos. En Brasil se llamó En Busca de la Venganza y en Taiwán Belleza Negra Maligna, quizá en estos países, el título de Colombiana no significara lo mismo que en Estados Unidos y por ese motivo se eligieron otros nombres que implicaran otro tipo de relación con el contenido del filme. Esto nos lleva a mirar el caso de Delta Force, en el que la omisión o camuflaje de lo colombiano tampoco afectó la narrativa. Tanto en Colombiana como en Delta, el lugar de origen no es lo más relevante ${ }^{13}$, como sí lo es la declaración estética y narrativa de que provienen de un lugar lejano y exótico, sea cual sea.

\section{Conclusiones: La representación exótica de Colombia en los filmes}

El cine de ficción no tiene la obligación de ser fiel a la realidad; por el contrario, lo que busca es una interpretación del mundo en respuesta a razones artísticas, culturales, políticas e industriales. Según Ernst Gombrich $(1982)^{14}$, siempre es necesario un esquema, un punto de comparación, para representar e interpretar visualmente al mundo. En esta interpretación del mundo y sus habitantes, el estereotipo cinematográfico funciona como herramienta esquemática para transmitir mensajes ideológicos y estéticos. El estereotipo no tiene como único propósito referirse de manera negativa o positiva a un individuo, grupo o cultura. Dentro de sus funciones están también la de simplificar y organizar categorías de objetos y personas. Bruno Mazzara (1999) $)^{15}$ indica que para que exista un estereotipo debe haber una necesidad de simplificar el mundo, así como una necesidad de pertenencia, en la que grupos culturales defienden su visión del mundo y miran con desconfianza lo ajeno, y por último, debe haber una historia compleja de relación entre las culturas. Estas tres razones de la existencia del estereotipo pueden encontrarse en el presente análisis cinematográfico.

Las películas de Hollywood con sus imágenes de paisajes y tipos humanos deben ser pensadas como especies de inventarios de la diversidad cultural. Las películas aquí analizadas muestran colecciones de paisajes, climas, costumbres, ritos, ceremonias,

13 Frente a las protestas de organizaciones en Estados Unidos, como la hecha por el colectivo Por Colombia que pedía el cambio de título del filme, Zoe Saldaña, la actriz que caracterizó a Cataleya, respondió al The Wall Street Journal: "No me gusta meterme en la política, pero es una lástima que haya tanta gente ignorante. La protagonista podría haber sido de Puerto Rico, Goa (India) o China, pero Besson quería que fuera de Colombia". Lo interesante sería conocer porqué precisamente Besson se empeñaba en que fuera de este país.

14 Ernst H. Gombrich, "La verdad y el estereotipo" En: Arte e ilusión, 1960.

15 Bruno Mazzara, Estereotipos y prejuicios, 1999. 
organización política y social, formas de vestir, vivir, celebrar y comer. A partir de esos elementos se trazan comparaciones, se jerarquizan los pueblos latinoamericanos, según las costumbres y los valores norteamericanos. Reunir estas informaciones es la forma de abarcar y entender la diversidad humana desde sí mismos. La alteridad construida por las películas de Hollywood, más que referirse a Colombia, nos hablan de estereotipos y clichés ${ }^{16}$ construidos desde el interior de la propia cultura norteamericana.

Este tipo de productos audiovisuales, si bien tienen difusión mundial, son pensados y hechos para un público exclusivamente norteamericano ${ }^{17}$, sin importar lo impreciso, pintoresco o prejuicioso que las informaciones sobre determinado país puedan ser; además, sin considerar, los procesos de homogeneización que puedan llegar a generar.

Por estas razones, encontramos diversas películas que muestran a Colombia con una fauna de llamas, alpacas y otros camélidos, ambientes de selvas profundas, terrible clima tropical de altas temperaturas ${ }^{18}$, de lluvias torrenciales y habitantes indígenas o campesinos mestizos. Los mismos clichés se utilizan para casi todos los países latinoamericanos, desde México hasta Tierra del Fuego, la única diferencia palpable radica en el epígrafe que aparece identificando la ciudad o el país. Un espectador desavisado que tenga como único referente los filmes de Hollywood, podría pensar que los países latinoamericanos son muy parecidos y casi indistinguibles entre sí. Podríamos concluir que tanto para productores y cineastas, como para los espectadores norteamericanos, no importa la veracidad de lo que está siendo mostrado, lo que sí se espera es que estos epígrafes correspondan a ciudades y países reales.

Las películas de Hollywood crean imaginarios sobre la diversidad y lo exótico para diferenciar, entender y asimilar a los diversos pueblos del mundo ${ }^{19}$. Como diría Peter Burke

16 El concepto de Cliché se usa aquí en dos sentidos. El primero, se deriva del francés y se refiere a la matriz de los grabados usados para imprimir estampas. El segundo sentido, muchos de estos grabados repetían incesantemente las mismas imágenes con ninguna o con mínimas modificaciones. Es así como, la palabra cliché explica esa constante repetición de esquemas visuales en las películas extranjeras sobre Colombia.

17 Aunque esto de pensar los filmes para un público exclusivo norteamericano ha ido cambiando en los últimos años, obligando a estudios, productores y cineastas a ampliar sus perspectivas, precisamente porque las recaudaciones de las películas en el mercado internacional ya son fundamentales, correspondiendo en promedio a un sesenta por ciento, mientras que las del mercado americano, ya son más reducidas, en general a un cuarenta por ciento.

18 En las películas de Hollywood el clima de Colombia es caracterizado por las fuertes y constantes lluvias, altas temperaturas, que contrastan con las imágenes de grandes ciudades americanas, con el cielo despejado y un clima templado o frío, asociado al nivel de desarrollo de su sociedad. El mensaje es claro: el atraso de las sociedades latinoamericanas, se debe al terrible clima de los trópicos. Esas creencias que vienen desde la antigüedad, los griegos y las Antípodas y fueron retomadas en las teorías del siglo xviII y xIx para explicar los estados de civilización entre Europa y el resto del mundo. Sobre este tema en el siglo XIX consultar el texto de Carl Henrik Langebaek, Geografía y pasado prehispánico: La formación de una nación, en Diana Bonnet y Felipe Castañeda, El Nuevo Mundo: problemas y debates, Bogotá, Universidad de los Andes, 2004, pp. 323-338.

19 El hecho de que en el cine de Hollywood no haya problema en que actores mexicanos o filipinos representen a colombianos es fascinante para entender las dinámicas de representación. No hay algo que particularice a lo colombiano frente a otros pueblos, dentro de los estereotipos, los latinoamericanos son iguales. 
(2005) "... Es la analogía lo que hace inteligible lo exótico, lo que lo domestica..." (p.156). Así los estereotipos del cine parten de una construcción consciente o inconsciente de otra cultura como opuesta a la propia. Representar visualmente cualquier cosa desconocida presentaba mayores dificultades y por eso los artistas preferirán copiar y repetir imágenes ya existentes. Ernst H. Gombrich (1995) ya había anticipado parte de la respuesta en sus investigaciones sobre imágenes y que podemos aplicar aquí para entender el porqué de la constante repetición de los mismos clichés por parte de diversos cineastas de Hollywood: "Lo familiar será, siempre, el punto de partida para la representación de lo desconocido; una representación existente ejerce siempre una cierta fascinación sobre el artista" (p. 88).

Colombia es exótica, según el cine que analizamos, porque es exagerada en todas sus dimensiones representativas. Desde el punto de vista estético y narrativo, el cine de Hollywood proyecta una Colombia naturalmente frondosa y socialmente excedida. Desde lo exuberante e intrincado de sus campos, pasando por la exagerada construcción de sus personajes que acostumbran ser extremistas, y finalizando en el descontrol de sus ciudades, Colombia se escenifica como una república de los trópicos donde nada que le pertenezca o la defina puede ser moderado. Los tres casos de películas analizadas evidencian algunos estereotipos colombianos constantemente presentados en el cine de Hollywood; la vegetación, los climas, las ciudades, los campos y las gentes son llevados al límite para representar un país de extremos.

En este recorrido por películas pertenecientes a tres décadas distintas, vemos cómo Colombia comienza por ser un territorio exótico y virgen; luego, gracias a sus tesoros escondidos, se convierte en un territorio de descontrol, para finalizar con una Colombia de la que sus habitantes deben emigrar. En el cine internacional de los años 80 fue común hablar de Colombia en términos de sus exóticas riquezas naturales, por más peligrosas que estas fueran. Romancing the Stone y Green Ice (1981) son dos ejemplos de películas que tratan el tema de las esmeraldas y los tesoros escondidos en tierras colombianas. Luego vemos como en los años 90 el tema del narcotráfico se hace más presente. La droga como un nuevo y peligroso tesoro extraído de tierras colombianas es el tema central en Delta Force II y también en películas de Hollywood como Marked for Death (1990), McBain (1991) y Clear and Present Danger (1994). De este modo, y gracias a sus riquezas naturales, Colombia deja de ser un lugar casi virgen y apto para ser reconquistado, y pasa a ser un lugar de caos y descontrol, en el que sus tesoros atraen la guerra por el poder e influyen en la relaciones binacionales con Estados Unidos.

Es inevitable pensar en los inicios del siglo XVI y las confusiones de los europeos con las Indias Orientales (Asia, India, China y Japón) y las Indias Occidentales (América y el Caribe). Los cronistas y viajeros ya encontraban similitudes físicas entre los asiáticos y los indígenas americanos. Además confusiones, como la de Cristóbal Colón que pensó haber llegado a Asia y no reconoció que se encontraba ante un nuevo continente (Chicangana, 2008). En las primeras décadas del siglo XVI las imágenes sobre los habitantes del actual Brasil, los Tupinambá, se convirtieron en referente para representar no solo a los habitantes de América, sino también a los de India, proceso conocido como "Tupinización". No muy diferente a lo que ocurriría con México en los años 1980, que fue referente cultural y étnico para representar a Latinoamérica, en un proceso de "mexicanización". 
Finalmente, vemos cómo para la década del 2000, los extravagantes y peligrosos personajes que vivían en la exótica Colombia prefieren emigrar a otros países que les ofrezcan las condiciones de vida óptimas que Colombia no les dio. Es común ver en esta década películas de Hollywood que tratan de manera insistente la inmigración de colombianos a los Estados Unidos; es el caso de Colombiana y de otros filmes como Entre Nos (2009) y Oh, my Soul (2009). Tal parece que lo exótico trae el caos y los colombianos prefieren irse a otros mundos más civilizados aunque lleven con ellos el caos interno como herencia y estigma por haber nacido en los trópicos.

Existen otros filmes de Hollywood que tratan el tema colombiano; sin embargo, los seleccionados aquí permiten un análisis más profundo, gracias a que se enfocan en Colombia durante la mayor parte de su narrativa. El despliegue audiovisual sobre lo colombiano que ofrecen estas películas nos ha permitido vislumbrar tendencias de representación estética y narrativa de lo latinoamericano en el Hollywood de las últimas tres décadas. Sin embargo, a pesar de poner en escena hechos, sujetos y lugares que tal vez existieron o existen, el cine no se puede considerar como el espejo de la realidad. Romancing the Stone, Delta Force II y Colombiana, sugieren que debemos tomar al cine como un transmisor de ideología, mas no necesariamente de la verdad, puesto que el cine interpreta, representa y escenifica, dándole connotaciones estéticas y políticas al mensaje según el contexto en el que se desarrolle el filme. Las tres películas expuestas en este artículo ofrecen una visón mediada sobre culturas ajenas que pueden influir en los cánones de representación cinematográficos venideros, construyendo una suerte de esquema representativo apto para usarse a la hora de representar al país y sus regiones aledañas.

\section{Fuentes Cinematográficas}

Andrew Davies, Collateral Damage, (2002).

Aaron Norris, Delta Force 2: The Colombian Connection, (1990).

Dwight H. Little, Marked for Death (1990).

Ernest Day, Green Ice, (1981).

Gloria La Morte y Paola Mendoza, Entre Nos (2009).

James Glickenhaus, McBain (1991).

Nicholas Monsour, Oh my Soul (2009).

Olivier Megaton, Colombiana, (2011).

Phillip Noyce, Clear and Present Danger (1994).

Robert Zemeckis, Romancing the Stone (1984).

Richard Lester, Superman III (1983).

Stuart Rosenberg y Alan Smithee, Let's Get Harry (1986).

\section{Referencias bibliográficas}

Burke, Peter. (2005). Visto y no visto. El uso de la imagen como documento histórico. Barcelona: Ed. Crítica.

Chartier, Roger. (1992). El mundo como representación. Historia cultural: entre práctica y representación. Barcelona: Gedisa, pp. 45-62. 
Chicangana-Bayona, Yobenj Aucardo. (2008). Fotogramas, alteridad y estereotipos: Colombia y los colombianos en el cine de Hollywood 1980-2006, en: Historia, trabajo, sociedad y cultura. Ensayos interdisciplinarios vol. 1. Medellín: La Carreta Editores, pp. 33-55.

(2008). "El nacimiento del caníbal: un debate conceptual", Revista Historia Crítica, Bogotá, n. 36, jul./dec, pp. 150-173.

Deleyto, Celestino. (2003). Ángeles y demonios: representación e ideología en el cine contemporáneo de Hollywood. Barcelona: Paidós.

Gombrich, E. H. (1982). La imagen y el ojo. Nuevos estudios sobre la sicología de la representación pictórica. Madrid: Alianza.

Martins Fontes, $3^{\mathrm{a}} \mathrm{ed}$.

(1995). Arte e Ilusão. Um estudo da psicologia da representação pictórica. São Paulo: Livraria

Hayward, Susan. (2010). "Stereotype." En Cinema Studies, the Key Concepts. Londres: Routledge, pp. 384.

Herkenhoff, Paulo. (1999). O Brasil e os holandeses 1630-1654. Río de Janeiro: Editorial Sextante Artes.

Langebaek, Carl Henrik. (2004). Geografía y pasado prehispánico: La formación de una nación. En: Diana Bonnet y Felipe Castañeda, El Nuevo Mundo: problemas y debates, Bogotá: Universidad de los Andes, pp. 323-338.

Mason, Peter. (1998). Infelicities. Representation of the Exotic. Baltimore: The Johns Hopkins University Press.

Mazzara Bruno, (1999). Estereotipos y prejuicios. Madrid: Acento Editorial.

Moscovici, Serge. (1979). "La Representación Social: un Concepto Perdido". En: El psicoanálisis, su imagen y su público. Buenos Aires: Editorial Huemul S.A., pp. 27-44.

Raminelli, Ronald. (1996). Imagens da Colonização. São Paulo: Jorge Zahar Editor.

(1999). Habitus Caníbal: Os Índíos de Albert Eckhout, en: Paulo Herkenhoff, O Brasil e os Holandeses 1630-1654. Rio de Janeiro: Sextante Artes, pp. 104-121.

Skar, Alba D. (2007). "El narcotráfico y lo femenino en el cine colombiano internacional: Rosario Tijeras y María llena eres de gracia". Alpha, n. 25, dic.

Smith, Bernard. (1992). European Vision and the South Pacific. New Haven and London: Yale University Press, 1988. Second Edition y Imagining the Pacific: In the Wake of the Cook Voyages. Yale University Press, New Haven and London.

Todorov, Tzvetan. (1991). Nosotros y los otros. Reflexión sobre la diversidad humana. México: Siglo XXI editores.

\section{Cibergrafía}

Barrero, Margarita. (2011). Recuperado el 9 de enero de 2012. Nueva heroína de cine es una bogotana que se convierte en sicaria. Disponible en: <http://m.eltiempo.com>.

Goldberg, Lesley. (2011). Recuperado el 9 de enero de 2012. "NBC Signs on to Adapt 'Romancing the Stone.'" Disponible en: < http://www.hollywoodreporter.com>.

"Romancing the Stone." Recuperado el 9 de enero de 2012. The Internet Movie Database (IMD6). Disponible en: <http://www.imdb.com/>. 